\title{
Levels and predictors of TB-HIV Diagnostic service linkage and testing in government hospitals of Southern zone of Tigray, Northern Ethiopia
}

\author{
Ashebir Mengistu Mitiku', Gebrezgi Zinabu Asfaw², Haftu Tesfahun Tsegay \\ Berhe Yodit Zewdie ${ }^{1}$, Atsibeha Mussie Tesfay ${ }^{3}$
}

1. School of Public Health, College of Health Sciences, Mekelle University, Mekelle, Ethiopia.

Email: mengistu.mitiku@yahoo.com

2. Department of Public Health, College of Health Sciences, Adigrat University, Adigrat, Ethiopia.

Email: zinabuasfaw6@gmail.com

3. Department of Health Systesm, School of Public Health, College of Health Sciences, Mekelle University,

Mekelle, Ethiopia Email: yoditzewdieb@gmail.com

4. School of Medicine, College of Health Sciences, Mekelle University, Mekelle, Ethiopia.

Email: moses28w@gmail.com

5. Private wing service, Ayder Comprehensive Specialized Hospital, College of Health of Health Sciences,

Mekelle University, Mekelle, Ethiopia. Email: ttsegay33@gmail.com

\begin{abstract}
Background: Tuberculosis (TB) and Human Immunodeficiency Virus (HIV) are global public health problems. TB and HIV diagnostic services linkage is imperative for the fight against the two diseases.

Objective: To assess the diagnostic service linkage and testing of TB-HIV diagnostic services and identify predictors in Public hospitals of Northern Ethiopia.

Methods: A cross-sectional study was conducted in five hospitals of Northern Ethiopia. Study subjects' socio-demographic, household and clinical variables were assessed.Data was analyzed using SPSS. Logistic regressions were used to determine the predictors of uptake of TB and HIV testing among HIV and TB patients, respectively.

Result: The level of HIV testing among TB patients was $94.4 \%$ and of TB screening among HIV patients was $90.5 \%$. Factors that independently predict HIV testing among TB patients were Residence AOR=0.187(95\% CI 0.05-0.76), being 9 grade and above $\mathrm{AOR}=13.17(95 \% \mathrm{CI} 2.67-65.03)$ and drinking alcohol $\mathrm{AOR}=0.03(95 \% \mathrm{CI}$ 0.002-0.475). Likewise, being grade 9 and above $\mathrm{AOR}=6.92(95 \% \mathrm{CI} 1.75-27.4)$ and having chronic cough $\mathrm{AOR}=0.23$ (95\% CI 0.06- 0.92) were predictor variables for having TB screening among HIV patients.

Conclusion: The levels of TB-HIV linkages and testing are high. Moreover, educational status is a strong predictor of TB screening among HIV patients and HIV testing among TB cases. The regional health bureau has to continue supporting its TB and HIV case teams in every health facility.
\end{abstract}

Keywords: TB-HIV Diagnostic service linkage, testing in government hospitals, Tigray, Northern Ethiopia.

DOI: https://dx.doi.org/10.4314/ahs.v19i3.5

Cite as: Mitiku AM, Asfaw GZ, Tsegay HT, Zewdie BY, Tesfay AM. Levels and predictors of TB-HIV Diagnostic service linkage and testing in government hospitals of Southern zone of Tigray, Northern Ethiopia. Afri Health Sci. 2019;19(3):2335-2346. https:/ / dx.doi.org/10.4314/

ahs.v19i3.5

\section{Corresponding author:}

Ashebir Mengistu Mitiku,

School of Public Health, College of Health Sciences

Mekelle University Tigray region, North Ethiopia

Office Tel: +251344406690

Mobile: +251914 727096

P.O. Box: 1871

Email: mengistu.mitiku@yahoo.com

\section{Background}

Mycobacterium tuberculosis and Immunodeficiency virus are bacterial and viral agents which bring about TB and AIDS respectively. After TB infection, a person with HIV have $10 \%$ annual risk and $60 \%$ life-time risk of developing TB disease, compared with a $10 \%$ life-time risk for persons without HIV, alarming for collaboration of services provided for both TB and HIV patients ${ }^{1}$.

The World Health Organization and Joint United Nations Program on HIV/AIDS estimate that one-third of

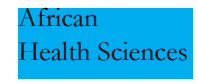

(C) 2019 Mitiku et al. Licensee African Health Sciences. This is an Open Access article distributed under the terms of the Creative commons Attribution License (https://creativecommons.org/licenses/BY/4.0), which permits unrestricted use, distribution, and reproduction in any medium, provided the original work is properly cited.

African Health Sciences Vol 19 Issue 3, September, 2019 
the 34 million people living with HIV and AIDS worldwide are co-infected with TB, one of the most common opportunistic infections ${ }^{2,3}$. People infected with HIV are up to 50 times more likely to develop TB than HIV-negative people, and not surprisingly, TB is the leading cause of death among HIV-infected individuals, despite the fact that $\mathrm{TB}$ is curable. ${ }^{3-5}$

According to HIV related estimates and projections for Ethiopia, the national prevalence of HIV infection in 2014 is $1.2 \%$ among adult population, with urban settings taking the lion share, i.e., 3.3\% prevalence and rural settings demonstrating a much lower prevalence. This is to say that HIV prevalence in rural settings is $0.5 \%$. Similarly, among TB patients tested for HIV, 15\% were HIV positives $^{6,7}$. Due to ths and the fact that TB remains the leading cause of death and morbidity among people living with HIV in developing countries ${ }^{8}$ and HIV infection is the most potent known risk factor associated with developing active $\mathrm{TB}^{9}$, diagnostic service collaboration between the services related to TB and HIV is mandatory. When TB-HIV collaborative services were implemented in Ethiopia, 10-15\% of annually notified TB patients were found to have HIV co-infection ${ }^{10,11}$. HIV infection, not integrated to TB service, could lead to progressive immunodeficiency and increased susceptibility to infections, including TB infection which could result in death, reduced quality of life and increased long term costs of treatment. The immune system, which defends our body from various infections and keeps us healthy as we drift through a sea of pathogens, is less able to prevent the growth and local spread of Mycobacterium tuberculosis, leading to the progression of recent or latent TB infection to active TB disease. As HIV infection progresses, the different cells of the immune system which mainly ncludes fighter cells like phagocytes, B lymphocytes and T lymphocytes, loses its power. CD4 lymphocytes, which are said to have a vital role in defending against foreign bodies, decline in number and function. ${ }^{12,13}$

For many years, attempts to tackle TB and HIV have been largely separate, despite the overlapping epidemiology. However, public health officials increasingly recognize that combined and coordinated efforts are the only way to halt the dual epidemics, and the Ethiopian Ministry of Health has made a significant investment in TB control and currently has created new post-2015 Global TB Strategy called "END TB strategy" which highlights TB-HIV co-infection ${ }^{8,14}$.
However, the Ethiopian ministry of health and its partners are not working hand-in-hand to support collaboration of TB-HIV services and to strengthen infection control. Moreover, there are no national and regional assessments done that show to what extent TB-HIV services are integrated at facility level. This research will, therefore, reveal the actual level of diagnostic linkage of TB-HIV services which is believed to be the key for the control of the dual epidemic.

\section{Methods \\ Description of study area}

The study was conducted in three general and two primary hospitals of Southern zone of Tigray, Northern Ethiopia. According to the Bureau of relations and information of Tigray, the Zone has 8 districts, namely: Alamata (with a total population of 49,795), Amba Alaje $(120,989)$, Endamekoni $(93,716)$, Korem $(25,190)$, Maichew $(35,067)$, Ofla $(138,563)$, Raya Alamata $(95,094)$ and Raya Azebo (154,861). There are 3 general hospitals, 2 primary hospitals and 86 health centres. TB and HIV services are comprehensively provided at hospital level. Southern zone, next to Western zone, is known to have a high prevalence of HIV, resulting in a huge burden of $\mathrm{TB}$ in the zone.

\section{Study design}

A facility based cross-sectional study was conducted in three general and two primary public hospitals of southern zone of Tigray, Northern Ethiopia

\section{Study population and Sample size determination}

All old TB and HIV care/ART patients registered in the TB and HIV care/ART treatment book in the past five years (September, 2011 to August, 2016) were considered as the source population and sampled systematically when they come for follow up. Based on the recent two months TB and HIV services data from all selected hospitals, the calculated sample sizes were distributed with probability proportional to size sampling technique. To select the study units from TB and HIV cases who attended TB and HIV departments in the selected hospitals, systematic random sampling method was used and every $4^{\text {th }}$ and $3^{\text {rd }}$ TB and HIV cases were selected starting from December - February, 2016 until the required number of sample sizes of 319 TB and 232 HIV cases were reached.

The sample size of this study was determined using single population proportion formula and considering $70.6 \%$ 
uptake of HIV testing among TB patients 17 and $82 \%$ uptake of TB screening among HIV patients 20 and taking the assumption of 5\% margin of error and 95\% confidence interval and 0.05 alpha level. Accordingly, the sample sizes were determined to be 319 and 232, respectively.

\section{Sampling method, data collection tool and study variables}

There are five public hospitals in Southern zone of Tigray region that provide TB and HIV care/ART services: Alamata, Korem and Maichew general hospitals as well as Mehoni and Adisho primary hospitals. All five were included in the study. The number of study participants allotted to each hospital was proportional to size allocation based on their TB and HIV care/ART clients flow. Study subjects were selected using systematic sampling technique when they come for follow up.

Review of TB and ART patients charts was done to determine the HIV testing and TB screening status using a data abstraction checklist and other necessary data elements difficult to obtain from the patient charts like residence, religion, educational background, occupation, access to tape water, electricity in the household, television in the household, fridge in the household were collected using exit interview questionnaire. Two indicators adapted from World Health Organization guidelines were used to assess the level of linkage that exists between TB and HIV care/ART services. These are 'proportion of TB patients tested for HIV' and 'proportion of HIV care/ ART patients screened for TB.' TB screening of HIV positives included five TB screening criteria indicated in the national TB guideline. The screening checklist included cough, fever, night sweats ( $>2$ weeks), weight loss $>$ $3 \mathrm{~kg}$ in the last 4 weeks and history of TB contact in the past 1 year. If the client said yes for cough $>2$ weeks or if no to cough $>2$ weeks but yes to two or more of the other questions the patient was further evaluated ${ }^{5}$. Pulmonary TB diagnosis (PTB) was confirmed if at least one sputum smear positive for AFB (Acid Fast Bacilli) was detected. The algorithm for smear negative PTB diagnosis required at least 2 slides negative for sputum $\mathrm{AFB}$, no response to broad spectrum antibiotic for 10-14 days, and radiographic abnormalities consistent with active TB; or, at least 2 slides negative for sputum AFB plus sputum culture positive for $M$. tuberculosis. Extra pulmonary TB (EPTB) diagnosis was confirmed based on FNA suggestive of, or consistent with, active extra pulmonary TB, one specimen from an extra pulmonary site culture positive for M.tuberculosis, or smear positive for AFB with the clinician's decision to treat the patient with a full course of anti-tuberculosis treatment. TB cases were recruited when they come for follow-up in the TB case team. TB patient charts were assessed to obtain data like sex, age, marital status, educational status, time since TB diagnosis, alcohol and cigarette smoking behaviors. Other data of TB cases like occupation, residence and household characteristics including the presence of $\mathrm{TB}$ and electricity were obtained through exit interview.

The data abstraction checklist and the questionnaire completed at the end of study subjects' service utilization were adapted from the revision of different literatures ${ }^{1,2,17-19}$. Proceeding to data collection, pre-testing on $10 \%$ of the sample size was done in Wukro general hospital, a neighboring hospital with similar setting and function to the study hospitals. 'HIV status of TB patients' and 'TB status of HIV patients' were the two dependent variables of this study. The independent variables were categorized as socio-economic and demographic characteristics, household and clinical variables.

\section{Data quality management and analysis}

The quality of the data was assured by proper design and pre-testing of the questionnaire. Data collectors and supervisors were trained. Every day, $10 \%$ of the questionnaires were randomly selected, reviewed and checked for completeness and relevance by the principal investigator and the necessary feedback was given to data collectors in the next day of data collection. Incomplete questionnaires were identified and refilled.

Data was entered, cleaned and analysed using SPSS version 20. Uni-variate analysis was also conducted to summarize demographic characteristics of respondents. Bi-variate analysis was also conducted to derive potential variables to be included in the binary regression analyses. The variables found significant at binary analysis were 
examined by Multivariate logistic regression analysis to control for confounding factors and determine the actual predictors for TB-HIV diagnostic service collaboration.

\section{Ethical considerations}

Ethical clearance with registration number of ERC 0896/2017 was obtained from the institutional review board of Mekelle University College of Health Sciences (MU-CHS) and official letter of cooperation was also written from MU-CHS to Tigray regional health bureau and the study hospitals. Consent was obtained from each participant after explaining their right not to participate if they would not be comfortable.

\section{Result}

\section{Socio-demographic characteristics of HIV cases}

A total of 232 charts of HIV cases were enrolled in this study. Females study subjects represent the majority of the group among HIV cases with 142 (61.2\%). The mean age of the respondents among TB cases was 31.45 with SD \pm 5.03 years. Most of the study subjects', 90 (38.8\%) age resides in the age category 26-34 years. Around 128(55.2\%) of the study subjects are urban area dwellers. Moreover, majority of the study subjects, $188(81.0 \%)$ are orthodox-tewahdo followers with 114 (49.2\%) of them being married. Among the 232 HIV cases, 165 (71.1\%) had no education. In addition, $67(28.8 \%)$ were farmers and 87 $(37.5 \%)$ were house wives in occupation. $220(94.8 \%)$ do not smoke cigarette and $213(92.7 \%)$ do not drink alcohol (Table 1).

Table 1: Bivariate analysis of socio-demographic characteristics of HIV cases in Southern zone primary and general hospitals of

Tigray, Northern Ethiopia, $2017(\mathrm{n}=232)$

\begin{tabular}{|c|c|c|c|c|c|}
\hline \multirow[b]{2}{*}{ Variable } & \multirow[b]{2}{*}{ Category } & \multicolumn{2}{|c|}{ TB status } & \multirow[b]{2}{*}{$\begin{array}{l}\text { Total } \\
\text { n(\%) }\end{array}$} & \multirow[b]{2}{*}{ p-value } \\
\hline & & $\begin{array}{l}\text { Screened } \\
\mathbf{n}(\%)\end{array}$ & $\begin{array}{c}\text { Not } \\
\text { screened } \\
\text { n(\%) }\end{array}$ & & \\
\hline \multirow[t]{3}{*}{ Sex } & & & & & 0.001 \\
\hline & Male & $74(35.2)$ & $16(72.7)$ & $90(38.8)$ & \\
\hline & Female & $136(64.8)$ & $6(27.3)$ & $142(61.2)$ & \\
\hline \multirow[t]{2}{*}{ Age } & & & & & 0.436 \\
\hline & Others & $10(4.8)$ & $5(22.7)$ & $15(6.5)$ & \\
\hline \multirow[t]{3}{*}{ Cigarette Smoking } & & & & & 0.001 \\
\hline & Yes & $6(2.9)$ & $6(27.3)$ & $12(5.2)$ & \\
\hline & No & $204(97.1)$ & $16(72.7)$ & $220(94.8)$ & \\
\hline \multirow[t]{3}{*}{ Alcohol drinking } & & & & & 0.001 \\
\hline & Yes & $13(6.2)$ & $6(19.0)$ & 19(7.3) & \\
\hline & No & 197(93.8) & $16(81.0)$ & $213(92.7)$ & \\
\hline Daily labourer & $57(27.1)$ & $6(27.3)$ & $63(27.2)$ & & \\
\hline
\end{tabular}

\section{Clinical data characteristics of HIV cases}

Among the 232 HIV cases, 112(48.3) were diagnosed HIV positive before 12 months. Around two-thirds of the study subjects $(59.1 \%)$ had haemoglobin level that ranged from $7-13 \mathrm{mg} / \mathrm{dl}$ and the CD4+ cell distribution across the three categories was almost similar, with
84(36.25) of the study subjects' CD4+ cell count laying in the range $200-349$. Around two-thirds (68.1\%) and majority $(87.5 \%)$ of the HIV cases were presented with fever and cough, respectively. Moreover, 216(90.1\%) of the cases had faced night sweats $>2$ weeks. 158(68.1\%) took cotrimoxazol and 203(87.5\%) received HAART (Table 2). 
Table 2: Clinical data characteristics of HIV cases in Southern zone primary and general hospitals of Tigray, Northern Ethiopia, 2017(n=232)

\begin{tabular}{|c|c|c|c|c|c|}
\hline \multirow[b]{2}{*}{ Variable } & \multirow[b]{2}{*}{ Category } & \multicolumn{2}{|c|}{ TB status } & \multirow[b]{2}{*}{ Total n(\%) } & \multirow[b]{2}{*}{ P-value } \\
\hline & & Screened $n(\%)$ & $\begin{array}{c}\text { Not screened } \\
\mathbf{n}(\%)\end{array}$ & & \\
\hline \multirow[t]{4}{*}{$\begin{array}{l}\text { Time since HIV } \\
\text { diagnosis }\end{array}$} & & & & & 0.026 \\
\hline & $<6$ months & $42(20.0)$ & $8(36.4)$ & $50(21.5)$ & \\
\hline & $6-12$ months & $62(29.5)$ & $8(36.4)$ & $70(30.2)$ & \\
\hline & $>12$ months & $106(50.5)$ & $6(27.2)$ & $112(48.3)$ & \\
\hline \multirow[t]{3}{*}{ Haemoglobin level } & & & & & 0.158 \\
\hline & Yes & $6(1.9)$ & $5(27.8)$ & $11(3.4)$ & \\
\hline & No & $295(98.1)$ & $13(72.2)$ & $308(96.5)$ & \\
\hline \multicolumn{6}{|l|}{ Alcohol } \\
\hline & Yes & $7(2.3)$ & $6(33.3)$ & $13(4.1)$ & \\
\hline & No & 294(97.7) & $12(66.7)$ & $306(95.9)$ & \\
\hline Time since TB dia & 10sis & & & & \\
\hline
\end{tabular}

Less than 6 month

\section{Predictors of TB screening among HIV cases}

Nine variables; namely sex, educational status with grade 9 and above, cigarette smoking, alcohol drinking, time since HIV diagnosis, cough, night sweats greater than 2 weeks and HAART were found to have association with the dependent variable, TB testing ( $\mathrm{p}$-value $<0.05$ ).

After adjustment for other variables was made, educational status with 9 grade and above, cough and patient receiving HAART were found to be independent predictors of TB testing among HIV patients.

The odds of TB screening was 6.9 times higher among
HIV patients who had no formal education $(\mathrm{AOR}=6.9$, 95\% CI: 1.75-27.4) as compared with HIV patients who were 9 grade and above.

HIV patients who hadn't had cough (AOR $=0.23,95 \%$ CI: 0.06-0.92) had 0.23 times higher odds of TB screening as compared to HIV patients who had had cough of three weeks.

Patients receiving HAART had an association with TB screening. The odds of getting TB testing were 5.08 times higher among those who receive HAART (AOR: 5.08, 95\% CI: 1.41-18.31) than those who don't receive HAART (Table 3). 
Table 3: Predictors of TB screening among HIV patients in Southern zone hospitals of Tigray, Ethiopia, 2017( $\mathrm{n}=232)$

\begin{tabular}{|c|c|c|c|c|c|}
\hline \multirow[b]{2}{*}{ Variable } & \multicolumn{2}{|c|}{ TB status } & \multirow[b]{2}{*}{ Total, n(\%) } & \multirow[b]{2}{*}{$\operatorname{COR}(95 \% \mathrm{Cl})$} & \multirow[b]{2}{*}{$\operatorname{AOR}(95 \% C l)$} \\
\hline & Screened $n(\%)$ & $\begin{array}{c}\text { Not screened } \\
n(\%) \\
\end{array}$ & & & \\
\hline \multicolumn{6}{|l|}{ Sex } \\
\hline Male & $74(35.2)$ & $16(72.7)$ & $90(38.8)$ & 1 & \multirow{2}{*}{$\begin{array}{c}1 \\
0.381(0.116- \\
1.252)\end{array}$} \\
\hline Female & $136(64.8)$ & $6(27.3)$ & $142(61.2)$ & $0.204(0.077-0.544)$ & \\
\hline \multicolumn{6}{|l|}{ Educational status } \\
\hline No education & $157(74.8)$ & $8(36.4)$ & $165(71.1)$ & 1 & \multirow{3}{*}{$\begin{array}{c}1 \\
3.790(0.868- \\
16.543) \\
\mathbf{6 . 9 2 2 ( 1 . 7 4 8 -} \\
\mathbf{2 7 . 4 1 4 ) *}\end{array}$} \\
\hline Grade 1-8 & $33(15.7)$ & $5(22.7)$ & $38(16.4)$ & $2.973(0.915-9.664)$ & \\
\hline Grade 9 and above & $20(9.5)$ & $9(40.9)$ & $17(12.5)$ & $8.831(3.060-25.49)$ & \\
\hline \multicolumn{6}{|l|}{$\begin{array}{l}\text { Cigarette } \\
\text { Smoking }\end{array}$} \\
\hline Yes & $6(2.9)$ & $6(27.3)$ & $12(5.2)$ & 1 & \multirow{2}{*}{$\begin{array}{c}1 \\
0.295(0.053- \\
1.636)\end{array}$} \\
\hline No & $204(97.1)$ & $16(72.7)$ & $220(94.8)$ & $0.078(0.023-0.271)$ & \\
\hline \multicolumn{6}{|l|}{ Alcohol } \\
\hline Yes & $13(6.2)$ & $6(19.0)$ & $19(7.3)$ & 1 & \multirow{2}{*}{$\begin{array}{c}1 \\
0.323(0.065- \\
1.607)\end{array}$} \\
\hline No & 197(93.8) & $16(81.0)$ & 213(92.7) & $0.176(0.059-0.525)$ & \\
\hline \multicolumn{6}{|l|}{$\begin{array}{l}\text { Time since HIV } \\
\text { diagnosis }\end{array}$} \\
\hline$<6$ months & $42(20.0)$ & $8(36.4)$ & $50(21.5)$ & 1 & \multirow{3}{*}{$\begin{array}{c}1 \\
0.757(0.201- \\
2.854) \\
0.311(0.082- \\
1.187)\end{array}$} \\
\hline 6-12 months & $62(29.5)$ & $8(36.4)$ & $70(30.2)$ & $0.677(0.236-1.946)$ & \\
\hline$>12$ months & $106(50.5)$ & $6(27.2)$ & $112(48.3)$ & $0.297(0.097-0.908)$ & \\
\hline \multicolumn{6}{|l|}{ Cough } \\
\hline Yes & $20(9.5)$ & $9(40.9)$ & $29(12.5)$ & 1 & \multirow{2}{*}{$\begin{array}{c}1 \\
0.232(0.059- \\
0.921)^{*}\end{array}$} \\
\hline No & $190(90.5)$ & $13(59.1)$ & $203(87.5)$ & $0.152(0.058-0.400)$ & \\
\hline \multicolumn{6}{|l|}{$\begin{array}{l}\text { Night sweet } \\
>2 \text { weeks }\end{array}$} \\
\hline Yes & $16(7.6)$ & $7(31.8)$ & $23(9.9)$ & 1 & \multirow{2}{*}{$\begin{array}{c}1 \\
0.620(0.141- \\
2.722)\end{array}$} \\
\hline No & 194(92.4) & $15(68.2)$ & $216(90.1)$ & $0.177(0.063-0.496)$ & \\
\hline \multicolumn{6}{|l|}{$\begin{array}{l}\text { Patient receiving } \\
\text { HAART }\end{array}$} \\
\hline Yes & $187(89.1)$ & $16(72.7)$ & $203(87.5)$ & 1 & \multirow[b]{2}{*}{$\begin{array}{c}5.076(1.407- \\
18.309) \\
\end{array}$} \\
\hline No & $23(10.9)$ & $6(27.3)$ & $29(12.5)$ & $3.049(1.085-8.569)$ & \\
\hline
\end{tabular}

\section{Socio-demographic characteristics of TB cases}

A total of 319 TB cases were enrolled in this study with females study subjects representing 168(52.7\%) of the total. The mean age of the study subjects was 30.5 with SD \pm 5 . The highest proportion of study subjects, $122(38.2 \%)$ belong to the age category $18-25$ years. $169(53.0 \%)$ of the study subjects are rural area dwellers. Moreover, majority of the study subjects, 227(71.2\%) are orthodox-tewahdo followers. With regard to marital status of the study subjects, married ones represented the highest figure with $175(54.9 \%)$. Moreover, study subjects with no education $186(58.3 \%)$, outweighed those with educational status. (Table 4). 
Table 4: Socio-demographic characteristics of TB cases in Southern Zone Primary and General hospitals of Tigray, Northern Ethiopia, $2017(\mathrm{n}=319)$

\begin{tabular}{|c|c|c|c|c|}
\hline \multirow[b]{2}{*}{ Variable } & \multirow[b]{2}{*}{ Category } & \multicolumn{2}{|c|}{ HIV status } & \multirow[b]{2}{*}{ Total n(\%) } \\
\hline & & Screened n(\%) & Not screened n(\%) & \\
\hline \multicolumn{5}{|l|}{ Sex } \\
\hline & Male & $162(33.8)$ & $6(33.3)$ & $168(52.7)$ \\
\hline & Female & $139(46.2)$ & $12(66.7)$ & $151(47.3)$ \\
\hline \multicolumn{5}{|l|}{ Age } \\
\hline & 18-25 Years & $115(38.2)$ & $7(38.9)$ & $122(38.2)$ \\
\hline & 26-34 Years & $97(32.2)$ & $6(33.3)$ & $103(32.3)$ \\
\hline & $>35$ Years & $89(29.6)$ & $5(27.8)$ & $94(29.5)$ \\
\hline \multicolumn{5}{|c|}{ Residence } \\
\hline & Urban & $137(45.5)$ & $13(72.2)$ & $150(47.0)$ \\
\hline & Rural & $164(54.5)$ & $5(27.8)$ & $169(53.0)$ \\
\hline \multicolumn{5}{|l|}{ Religion } \\
\hline & Orthodox & $217(72.1)$ & $10(55.6)$ & $227(71.2)$ \\
\hline & Muslim & $84(27.9)$ & $8(44.4)$ & $82(28.8$ \\
\hline \multicolumn{5}{|c|}{ Marital status } \\
\hline & Single & $116(38.6)$ & $6(33.3)$ & $122(38.2)$ \\
\hline & Married & $168(55.8)$ & $7(38.9)$ & $175(54.9)$ \\
\hline & Divorced & $17(5.6)$ & $5(27.8)$ & $22(6.9)$ \\
\hline \multicolumn{5}{|c|}{ Educational status } \\
\hline & No education & $180(59.8)$ & $6(33.3)$ & $186(58.3)$ \\
\hline & Grade 1-8 & $105(34.9)$ & 7 (38.9) & $112(35.1)$ \\
\hline & Grade 9 and above & $16(5.3)$ & $5(27.8)$ & $21(6.6)$ \\
\hline \multicolumn{5}{|c|}{ Occupation } \\
\hline & Farmer & $128(42.5)$ & $9(50.0)$ & $137(42.9)$ \\
\hline & House wife & $69(22.9)$ & $5(27.9)$ & $74(23.2)$ \\
\hline & Student & $41(13.6)$ & $2(11.1)$ & $43(13.5)$ \\
\hline & Merchant & $37(12.4)$ & $1(5.6)$ & $38(11.9)$ \\
\hline & Others & $26(8.6)$ & $1(5.6)$ & $27(8.5)$ \\
\hline
\end{tabular}

\section{Household characteristics of TB cases}

Majority of the TB cases $(91.8 \%)$ had access to tap water. Many of the TB cases $(76.2 \%)$ have electricity in their household. With regard to television and fridge, around half $(54.5 \%)$ had television. However, around two thirds
$(68.7 \%)$ of the $\mathrm{TB}$ cases did not have fridge in their household. Almost all TB cases did not smoke cigarette with $308(96.5 \%)$ and did not drink alcohol with 306 (95.9\%). In addition, $139(43.6 \%)$ of the TB cases were diagnosed before 12 months (Table 5). 
Table 5: Household characteristics of TB cases in Southern Zone Primary and General hospitals of Tigray, Northern Ethiopia, $2017(n=319)$

\begin{tabular}{|c|c|c|c|c|c|}
\hline \multirow[b]{2}{*}{ Variable } & \multirow[b]{2}{*}{ Category } & \multicolumn{2}{|c|}{ HIV status } & \multirow[b]{2}{*}{ Total n (\%) } & \\
\hline & & $\begin{array}{c}\text { Screened n } \\
(\%)\end{array}$ & $\begin{array}{l}\text { Not screened } \\
n(\%)\end{array}$ & & \\
\hline \multicolumn{6}{|c|}{ Access to tape water } \\
\hline & \multirow{3}{*}{$\begin{array}{l}\text { Yes } \\
\text { No } \\
\text { Total } \\
\text { n(\%) }\end{array}$} & $280(93.0)$ & $13(72.2)$ & \multirow{3}{*}{$\begin{array}{c}293(91.8) \\
26(8.2)\end{array}$} & \\
\hline & & $21(6.9)$ & $5(27.8)$ & & \\
\hline & & $\operatorname{COR}(95 \% \mathrm{CI})$ & $\operatorname{AOR}(95 \% \mathrm{CI})$ & & \\
\hline \multicolumn{6}{|l|}{ Residence } \\
\hline Urban & $137(45.5)$ & $13(72.2)$ & $150(47.0)$ & \multirow{2}{*}{$\begin{array}{c}1 \\
0.321(0.112- \\
0.924)\end{array}$} & 1 \\
\hline Rural & $164(54.5)$ & $5(27.8)$ & $169(53.0)$ & & $\begin{array}{c}\text { 0.187(0.047- } \\
0.755)\end{array}$ \\
\hline \multicolumn{6}{|l|}{$\begin{array}{l}\text { Educational } \\
\text { status }\end{array}$} \\
\hline No education & $180(59.8)$ & $6(33.3)$ & $186(58.3)$ & \multirow{3}{*}{$\begin{array}{c}1 \\
2.000(0.655- \\
6.109) \\
9.375(2.575- \\
34-135)\end{array}$} & \multirow{3}{*}{$\begin{array}{c}1 \\
2.046(0.556- \\
7.536) \\
\mathbf{1 3 . 1 7 3 ( 2 . 6 6 9 -} \\
\mathbf{6 5 . 0 2 6 )}\end{array}$} \\
\hline Grade 1-8 & $105(34.9)$ & 7 (38.9) & $112(35.1)$ & & \\
\hline $\begin{array}{l}\text { Grade } 9 \text { and } \\
\text { above }\end{array}$ & $16(5.3)$ & $5(27.8)$ & $21(6.6)$ & & \\
\hline \multicolumn{6}{|l|}{$\begin{array}{l}\text { Access to tape } \\
\text { water }\end{array}$} \\
\hline Yes & $280(93.0)$ & $13(72.2)$ & 293(91.8) & \multirow{2}{*}{$\begin{array}{c}1 \\
5.128(1.669- \\
15.760)\end{array}$} & \multirow{2}{*}{$\begin{array}{c}1 \\
8.914(2.108- \\
37.687)\end{array}$} \\
\hline No & $21(6.9)$ & $5(27.8)$ & $26(8.2)$ & & \\
\hline \multicolumn{6}{|l|}{$\begin{array}{l}\text { Cigarette } \\
\text { Smoking }\end{array}$} \\
\hline Yes & $6(1.9)$ & $5(27.8)$ & $11(3.4)$ & \multirow[b]{2}{*}{$\begin{array}{c}0.053(0.014- \\
0.196)\end{array}$} & \multirow{2}{*}{$\begin{array}{c}1 \\
2.038(0.104- \\
40.115)\end{array}$} \\
\hline No & $295(98.1)$ & $13(72.2)$ & $308(96.5)$ & & \\
\hline \multicolumn{6}{|l|}{$\begin{array}{l}\text { Alcohol } \\
\text { drinking }\end{array}$} \\
\hline Yes & $7(2.3)$ & $6(33.3)$ & $13(4.1)$ & \multirow{2}{*}{$\begin{array}{c}1 \\
0.048(0.014- \\
0.164)\end{array}$} & \multirow{2}{*}{$\begin{array}{c}1 \\
0.032(0.002- \\
0.475)\end{array}$} \\
\hline No & 294(97.7) & $12(66.7)$ & $306(95.9)$ & & \\
\hline \multicolumn{6}{|l|}{$\begin{array}{l}\text { Time since } \\
\text { TB diagnosis }\end{array}$} \\
\hline$<6$ month & $52(17.3)$ & $8(44.4)$ & $60(18.8)$ & \multirow{3}{*}{$\begin{array}{c}1 \\
0.033(0.088- \\
0.905) \\
0.017(0.076- \\
0.775)\end{array}$} & \multirow{3}{*}{$\begin{array}{c}1 \\
0.336(0.083- \\
1.356) \\
0.329(0.085- \\
1.267)\end{array}$} \\
\hline 6-12 months & $115(38.2)$ & $5(27.8)$ & $120(37.6)$ & & \\
\hline$>12$ months & $134(44.5)$ & $5(27.8)$ & 139(43.6) & & \\
\hline
\end{tabular}

\section{Predictors of HIV testing among TB cases}

Six variables; namely residence, educational status(being 9 grade and above), access to tap water, cigarette smoking, alcohol drinking and time since TB diagnosis were found to have association with the dependent variable, HIV testing ( $\mathrm{p}$-value $<0.05$ ).
After adjustment for other variables was made, residence, being 9 grade and above, access to tap water and alcohol drinking were found to be independent predictors of having an HIV test. 
The odds of getting HIV test was 0.19 times lower among rural residents $(\mathrm{AOR}=0.19,95 \% \mathrm{CI}: 0.05-0.76)$ compared with TB patients who were residents of the urban area. TB patients whose educational status was 9 grade and above (AOR=13.17, 95\% CI: 2.67-65.03) had 13.17 times higher odds of getting HIV test as compared to TB patients with no education.
Access to tap water had an association with getting HIV test. The odds of getting HIV test was 8.90 times higher among TB patients who had access to tap water (AOR: 8.90, 95\% CI: 2.11-37.69) than those who had no access. The odds of getting HIV test among TB patients who didn't have the habit of drinking alcohol $(A O R=0.03$, 95\% CI: 0.02-0.48) was 0.03 times lower as compared to their counterparts (Table 6 ).

Table 6: Predictors of HIV testing among TB patients in Southern Zone of Tigray Primary and General Hospitals, Northern Ethiopia, 2017 ( $\mathrm{n}=319)$

\begin{tabular}{|c|c|c|c|c|c|}
\hline \multirow[b]{2}{*}{ Variable } & \multicolumn{2}{|c|}{ HIV status } & \multirow[b]{2}{*}{$\begin{array}{l}\text { Total } \\
\text { n(\%) }\end{array}$} & \multirow[b]{2}{*}{$\operatorname{COR}(95 \% \mathrm{CI})$} & \multirow[b]{2}{*}{$\operatorname{AOR}(95 \% C I)$} \\
\hline & Screened $n(\%)$ & $\begin{array}{c}\text { Not } \\
\text { screened } \\
\mathbf{n}(\%) \\
\end{array}$ & & & \\
\hline \multicolumn{6}{|l|}{ Residence } \\
\hline Urban & $137(45.5)$ & $13(72.2)$ & $150(47.0)$ & $\begin{array}{c}1 \\
0.321(0.112- \\
0.924)\end{array}$ & $\begin{array}{c}1 \\
0.187(0.047- \\
0.755)\end{array}$ \\
\hline \multicolumn{6}{|l|}{$\begin{array}{l}\text { Educational } \\
\text { status }\end{array}$} \\
\hline No education & $180(59.8)$ & $6(33.3)$ & $186(58.3)$ & \multirow{3}{*}{$\begin{array}{c}1 \\
2.000(0.655- \\
6.109) \\
9.375(2.575- \\
34-135)\end{array}$} & \multirow{3}{*}{$\begin{array}{c}1 \\
2.046(0.556- \\
7.536) \\
\mathbf{1 3 . 1 7 3 ( 2 . 6 6 9 -} \\
\mathbf{6 5 . 0 2 6 )}\end{array}$} \\
\hline Grade 1-8 & 105(34.9) & 7 (38.9) & $112(35.1)$ & & \\
\hline $\begin{array}{l}\text { Grade } 9 \text { and } \\
\text { above }\end{array}$ & $16(5.3)$ & $5(27.8)$ & $21(6.6)$ & & \\
\hline \multicolumn{6}{|l|}{$\begin{array}{l}\text { Access to tape } \\
\text { water }\end{array}$} \\
\hline Yes & 280(93.0) & $13(72.2)$ & 293(91.8) & \multirow{2}{*}{$\begin{array}{c}1 \\
5.128(1.669- \\
15.760)\end{array}$} & \multirow{2}{*}{$\begin{array}{c}1 \\
\begin{array}{c}1 \\
\text { 8.914(2.108- } \\
37.687)\end{array}\end{array}$} \\
\hline No & $21(6.9)$ & $5(27.8)$ & $26(8.2)$ & & \\
\hline \multicolumn{6}{|l|}{$\begin{array}{l}\text { Cigarette } \\
\text { Smoking }\end{array}$} \\
\hline Yes & $295(98.1)$ & $5(27.8)$ & $11(3.4)$ & $\begin{array}{c}0.053(0.014- \\
0.196)\end{array}$ & $\begin{array}{c}1 \\
2.038(0.104- \\
40.115)\end{array}$ \\
\hline \multicolumn{6}{|l|}{$\begin{array}{l}\text { Alcohol } \\
\text { drinking }\end{array}$} \\
\hline Yes & $7(2.3)$ & $6(33.3)$ & $13(4.1)$ & \multirow{2}{*}{$\begin{array}{c}1 \\
0.048(0.014- \\
0.164)\end{array}$} & \multirow{2}{*}{$\begin{array}{c}1 \\
0.032(0.002- \\
0.475)\end{array}$} \\
\hline No & 294(97.7) & $12(66.7)$ & $306(95.9)$ & & \\
\hline \multicolumn{6}{|c|}{$\begin{array}{l}\text { Time since TB } \\
\text { diagnosis }\end{array}$} \\
\hline$<6$ month & $52(17.3)$ & $8(44.4)$ & $60(18.8)$ & \multirow{3}{*}{$\begin{array}{c}1 \\
0.033(0.088- \\
0.905) \\
0.017(0.076- \\
0.775)\end{array}$} & \multirow{3}{*}{$\begin{array}{c}1 \\
0.336(0.083- \\
1.356) \\
0.329(0.085- \\
1.267)\end{array}$} \\
\hline $6-12$ months & $115(38.2)$ & $5(27.8)$ & $120(37.6)$ & & \\
\hline$>12$ months & $134(44.5)$ & $5(27.8)$ & $139(43.6)$ & & \\
\hline
\end{tabular}




\section{Discussion}

HIV testing among TB patients and the inverse is a major way of tackling TB and HIV infection and a base for collaboration of TB and HIV services at health facility ${ }^{1-4}$. Understanding the diagnostic services collaborative activity of TB and HIV and their predicting factors is very essential for countries where the prevalence and burden of TB and HIV is high. Thus, this study assessed the diagnostic collaboration of TB and HIV services and factors related with the uptake of HIV testing among TB patients and the reverse in Southern zone of Tigray, Northern Ethiopia.

This study showed that the uptake of TB screening among HIV patients is $90.5 \%$ and the proportion of TB patients undergoing HIV testing is found to be $94.4 \%$. Moreover, the current study revealed that HIV patients who had completed at least grade 9, presented with cough and receiving HAART were independent predictors of TB screening. Similarly, residence, being grade 9 and above, having access to tap water and alcohol drinking were factors associated with HIV testing among TB patients.

In this study, the uptake of TB testing among HIV patients in Southern zone of Tigray region, Northern Ethiopia was $90.5 \%$. This is in line with the national policy of TB and HIV where all HIV patients with a symptom of cough are expected to undergo TB screening. However, the finding is not comparable with a study conducted in Ghana ${ }^{15}$ where $63.2 \%$ of HIV cases underwent TB screening. This low figure could be due to the existence of different level of the prevalence and burden of TB and HIV in between the two nations and consequently the presence of different HIV and TB related policies. Moreover, the Ethiopian Ministry of Health recommendation with regard to TB-HIV collaborative activity is proving to be successful as the minimum percentage of TB screening among HIV patients, which is placed at $85 \%$, is surpassed.

The uptake of HIV testing among TB patients as revealed in this study is $94.4 \%$. The Ethiopian Ministry of Health developed a guideline and recommends all $\mathrm{TB}$ patients to undergo HIV screening. The result showed the effectiveness of the policy and its implementation in the Ethiopian health care system. Moreover, this finding is consistent with the result from a study conducted in three districts of South Africa ${ }^{16}$. This could be due to the existence of a health system policy which enhances TB and HIV services collaboration. However, the current study's finding as compared to the findings obtained from other studies conducted in North West Ethiopia and Uganda ${ }^{17,18}$ were higher. This could be due to the fact that the time when the studies in NorthWest Ethiopia and Uganda were conducted was when the community awareness about TB and HIV was low which finally brought about low uptake of HIV testing. Furthermore, there might not be a good health system policy some years before in Ethiopia and Uganda.

Statistical association was established between educational status (being 9 grade and above) of HIV patients and getting screened for TB implying that further awareness creation activities in the community should be focused on. In this study, HIV patients who completed at least 9 grade were with higher odd of getting screened for TB than those who had no formal education. This finding is not consistent with the evidence from a study undertaken in Ghan ${ }^{15}$ where educational status was not independent predictor of getting TB screening among HIV patients. This might be due to the level of behavioral change that the community exhibits, not the level of education community members attained. However, chronic cough, like the finding from the current study is found to be an independent predictor variable of TB screening among HIV patients as evidenced by a study conducted in Ghana ${ }^{15}$.

The odds of having an HIV test among TB patients who dwell in urban areas were higher than TB patients who dwell in rural areas. This finding was comparable with the studies from Uganda and South Africa ${ }^{16,18}$. It is known that people living in rural areas have less access to education than their counterparts. This brings a good return in the overall change in behavior of the urban area dwellers which finally brings about full awareness about the benefit of HIV testing. This finding supports the fact that, in Ethiopia where policy development almost treats urban and rural areas equally, further revision of the directions is important if similar behavioral change of the community is expected to happen.

TB patients' level of education (being 9 grade and above) was significantly associated with getting tested for HIV. The odds of TB patients who completed at least 9 grades were higher in getting HIV test than those with no formal education. This is in line with other studies done in East 
Gojam, Ethiopia ${ }^{17}$. This might be due to the existence of HIV patients with similar socio-demographic characteristics across the two study areas. On the other hand, the finding from South Africa and Uganda ${ }^{16,18}$ is not in line with the finding from the current study as it is the cognitive thinking and behavioral change that matters with regard to the existence of higher uptake of HIV testing.

The use of alcohol is another important variable associated with having HIV test among TB patients. TB patients who did utilize alcohol were more likely to have HIV test than those who didn't utilize. This finding is not consistent with studies done in South Africa and China ${ }^{16,19}$. It is known that alcohol consumption is among the main pre-disposing factors for sexually transmitted infections. Therefore, TB patients who usually drink alcohol has the tendency to face STI and hence making themselves target ones for HIV screening.

\section{Conclusion and recommendation}

Diagnostic collaboration (the uptake of TB screening among HIV patients and HIV testing among TB cases) is very good in public hospitals of Southern zone of Tigray. The Tigray region health bureau should continue supporting its Public hospitals in linking TB and HIV services. Moreover, awareness creation activities should be done to TB and HIV patients in particular and the community in general regarding the benefits of HIV testing and TB screening.

\section{Limitations}

Generalizing the finding of this study to other settings of the study area and of Ethiopia is fairly possible as this study included participants from urban and rural settings and the socio-demographic characteristics of patients in Ethiopia is similar.

\section{Acknowledgements}

We would like to acknowledge Mekelle University for securing ethical approval of this project through its Health Research Ethics Review Committee. We are also grateful to Tigray regional health bureau and its woreda health offices for supporting the implementation of the research. We also thank data collectors for the valuable data they helped us gather during the data collection period, and the study subjects for their willingness to participate in this study.

\section{Funding}

Mekelle University through its recurrent budget funded and supported this research work with a project registration number of CRPO/CHS/SM/021/2017.

\section{Conflict of interest}

The authors have no conflicts of interest.

\section{Reference}

1. Federal Ministry of Health of Ethiopia. Implementation Guideline for TB-HIV Collaborative Activities in Ethiopia. 2013

2. World Health Organization (WHO). Global tuberculosis and HIV report, 2014.

3. United Nations Programme on HIV/AIDS (UNAIDS). Global HIV and TB co-infection report, 2014.

4. Centers for Diseases Control and Prevention. Fact sheet, 2016.

5. U.S. President's Emergency Plan for AIDS Relief. Fact sheet, 2012

6. Federal Ministry of Health of Ethiopia. National Comprehensive HIV Care and Treatment Training manual for Health care Providers. June, 2014

7. Federal Ministry of Health of Ethiopia. National comprehensive tuberculosis, leprosy and TB-HIV training manual for health care workers. 2016.

8. Stop TB partnership. The global plan to stop TB 2011 2015: transforming the fight towards elimination of tuberculosis. Geneva, Switzerland: World Health Organization, 2010.

9. Bock N, Reichman LB. Tuberculosis and HIV/AIDS: epidemiological and clinical aspects (world perspective). Semin Respir Crit Care Med. 2004; 25: 337-344.

10. World Health Organization (WHO), Global tuberculosis report, 2013.

11. Ethiopian Federal Ministry of Health. TB-HIV surveillance report, 2012.

12. AIDS Control and Prevention Project of Family Health Internal, The Francois-Xavier Bagnoud Center for Public Health and Human Rights Of the Harvard School of Public Health, UNAIDS. The Status and Trends of the Global HIV /AIDS Pandemic. Final Report July.1996. 13. Raviglione MC, Narain JP, Kochi A. HIV-associated tuberculosis in developing countries: clinical features, diagnosis, and treatment. Bull WHO 1992;70(5):15-526.

14. Helena LG, Catherine M, Palwasha K, Rifat A, Ade F, Haileyesus G., et al. Integrating tuberculosis and HIV 
services in low- and Middle-income countries: a systematic review. Tropical Medicine and International Health. 2013;18(2):199-211.

15. Susanne M, Torsten F, Fred S. and Kirsten A Eberhard. Factors associated with performing tuberculosis screening of HIV-positive patients in Ghana: LASSO-based predictor selection in a large public health data set. BMC Public Health. 2016;16:563.

16. Peltzer K, Mchunu G, Tutshan B, Naidoo P, Matseke G, Louw J. Predictors of Non-Uptake of human immunodeficiency virus testing by tuberculosis public primary patients in three districts, South Africa. Iranian J Publ Health. 2012;41(11):19-26.

17. Animut A, Abenet L, Robert C, Amare Deribew. Predictors of HIV testing among patients with tuberculosis in North West Ethiopia: A Case-Control Study. PLoS One. 2010; 5(3). e9702.

18. Ibrahim S, Imke S, Mesach M, Maarten L, Frank C, Joseph L. Low HIV testing rates among tuberculosis patients in Kampala, Uganda. BMC Public Health. 2010;10:177.

19. Junjie $X$, Weiming $T$, Shiming $C$, Tanmay M, Lin $Z$, Yuji L, et al. Prevalence and predictors of HIV among Chinese Tuberculosis patients by provider-initiated HIV testing and counselling (PITC): A Multisite study in South Central of China. PLoS One. 2014; 9(2).

20. Aragie K, Degu J, Yibeltal A, Azmera T, Abraham A, Amare D., et al. Evaluation of collaborative TB-HIV activities in a general hospital in Addis Ababa, Ethiopia, BMC Research. 2012;25 